\title{
ANTROPOMORFISMO E ZOOMORFISMO NO CONTO "FUGA" DE JOHN STEINBECK"
}

\author{
Sigrid Renaux \\ Universidade Federal do Paraná
}

\begin{abstract}
RESUMO:
Este artigo pretende mostrar como podemos tratar textos literários de modo mais produtivo através de uma aná. lise de texto, que permile aos alunos perceberem como a lingua está estruturada em liceratura. Para tanto foram escolhidos trechos descritivos do conto "Flight" de John Steinbeck que mostram, por um lado, como a natureza se torna antropomórfica c, por outro lado, como o herói, Pepé, gradualmente se zoomorfisa, deste modo intensificando as relações entre espaço e personagem.
\end{abstract}

Como professora de literatura inglesa e norte-americana da Universidade Federal do Parana há mais de dez anos, cheguei à conclusão de que uma abordagem literária através de uma análise de texto realmente produz bons resultados.

Levando-se em consideração que o aluno médio do Curso de Letras, após estudar lingua inglesa durante dois anos que corresponderiam aproximadamente ao mesmo nivel de um aluno que está se preparando para o Cambridge First Certificate - irá então estudar literatura inglesa e norteamericana por mais dois anos; mas que, por outro lado, ele provavelmente irá ensinar inglês no segundo grau e deste modo usará sua habilidade linguiistica muito mais do que seu conhecimento de literatura - por que não transformar o ensino da literatura num estimulante jogo ou exercicio de língua? Desta maneira, os professores de literatura estariam trabalhando em duas direções ao mesmo tempo, mostrando mais uma vez que língua e literatura são na realidade um todo, que é apenas separado artificialmente para fins didáti-

\footnotetext{
- A primeira parte deste artico (referentc so antropomorfismo) encontra-se publicada no original inglis gob o título “Stelnbeck's Flight: Language through Literature, Arain". em Enjlish Tcaching Forum, 20(4):6-8.14, Oct. 1982.
} 
cos. E o que é uma análise de texto, se não uma percepção mais aprofundada de como a lingua está estruturada em literatura?

Partindo deste ponto de vista, vamos examinar, entre tantos textos que poderiam ser usados para exemplificar esta técnica de abordagem, alguns trechos do conto "Fuga" de John Sieinbeck (1902-1968), escrito na década de trinta. $O$ texto reflete a paisagem de sua terra natal, a península de Monterey na Cailfórnia e que, no inicio deste século, ainda era praticamente inexplorada; reflete também o conhecimento que Steinbeck possuia dos trabalhadores e fazendeiros mexicanos que conhecera em sua juventude.

Como o título sugere, esta é a estória de Pepé, um rapaz magrinho e desajeitado que, tendo sido encarregado pela mãe de ir até a cidade de Monterey para comprar remédios e comida, sem querer mata um homem e portanto tem de deixar a pequena fazenda em que mora com sua mãe e irmãos para fugir para as montanhas, para sobreviver, pois assim o exige seu código moral de mestiço. Mas suas chances de sobrevivência diminuem paralelamente com a mudança que ocorre na natureza da regiäo que ele atravessa - de benigna e fértil a hostil e estéril - até que no final sua morte se torna inevitável. $\mathrm{E}$, apesar de Pepé ter se tornado gradativamente semelhante a um animal selvagem, ao ser despojado de seus trajes e do equipamento que o identificavam como pertencendo à civilização, ele morre como um homem - ele que antes de cometer um assassinato, ainda era um rapazinho.

Assim que o aluno inicia a leitura do texto, ele se defronta com um trecho descritivo:

About fifteen miles below Monterey, on the wild coast, the Torres family had their farm, a few sloping acres above a cliff that dropped to the brown reefs and to the hissing white waters of the ocean. Behind the farm the stone mountains stood up against the sky. The farm buildings huddled like the clinging aphids on the mountain skirts, crouched low to the ground as though the wind might blow them into the sea. The little sack, the rattling, rotting barn were gray-bitten with sea salt, beaten by the damp wind until they had taken on the color of the granite hills. Two horses, a red cow and a red calf, half a dozen pigs and a flock of lean, multicolored chickens stocked the place. A little corn was raised on the sterile slope, and it 
grew short and thick under the wind, and all the cobs formed on the landward sides of the stalks. (...)

O que o aluno percebe, numa primeira leitura? Provavelmente que o espaço da ação é uma fazenda perto de Mon. terey, cercada pelo oceano e pelas montanhas, e que além de um velho barracão, há alguns animais domésticos por ali, como também uma pequena plantação de milho. Isto, tratando-se de um leitor inexperiente. Agora é tarefa do professor - esteja ele lecionando lingua ou literaiura - mostrar ao aluno que este primeiro parágrafo nos diz muito mais, pois ele estabelece a atmosfera do conto, que é a de uma natureza hostil e estéril, contra a qual o homem, minúsculo, insignificante, ousa lutar, e esta atmosfera é transportada através do conto até o final. Nós teremos apenas de examinar as palavras usadas, para nos tornarmos suscetiveis e podermos captar a força e riqueza que encerram.

A fazenda, já localizada na costa brava ("on the wild coast"), é ainda mais prejudicada pelo fato de que consiste em alguns acres inclinados ("a few sloping acres") e além disso, existe também uma implicaçāo de perigo, pois estes acres estão acima de um rochedo que descia até os recifes escuros e as sibilantes águas brancas do oceano ("above a cliff that dropped to the brown reefs and to the hissing white waters of the ocean"), com a sugestão de as águas terem vida, em seu movimento e som. A fazenda está assim encurralada entre os rochedos e o mar, de um lado, e as montanhas de granito que se erguiam contra o céu ("the stone mountains stood up against the sky") por outro. O contraste entre um cenário natural todo-poderoso e as tentativas do homem em domá-lo é realçado ainda mais na frase seguinte, através de uma analogia entre as construções da fazenda que estão amontoadas, apinhadas ("huddled") na vertente da montanha, como pulgōes que se agarram às plantas, agachadas bem ao solo, como se o vento pudesse soprálas para dentro do mar ("the farm buildings huddled like the clinging aphids on the mountain skirts, crouched low to the ground as though the wind might blow them into the sea").

A fragilidade e a pequenez das construçōes da fazenda se tornam deste modo perceptiveis ao aluno, pelo fato de o escritor enfatizar sua semelhança a pequenos pulgões que se alimentam das plantas e, por extensão, pensamos nos moradores da fazenda, a familia Torres, como tendo as mesmas caracteristicas. Até a aliteração (técnica mais comum na poesia) é usada neste trecho, para reforçar esta impressão de fragilidade e impotência perante as forças da natureza em 
"clinging" e "crouched"; e a idéia de que, se não fosse por este ato de agarrar-se e agachar-se (até em português pode-se conseguir uma equivalência sonora), o vento poderia soprálos para dentro do mar, como insetos, novamente. $\mathrm{E}$ é interessante observar a ambiguiidade que se consegue em in. glês, pois a frase "crouched low (...)sea", pode referir-se tanto aos pulgões como às construçōes da fazenda, pois na traduçāo, o particípio passado já tem gênero e a ambigüidade desaparece.

A mesma idéia continua na frase seguinte, na qual são usados efeitos aliterativos mais uma vez para ressaltar a insignificância da fazenda: a pequena cabana, o celeiro barulhento e podre. Além disso, uma primeira pincelada de antropofagia é dada - que será gradativamente desenvolvida através do conto, sempre em relação com a natureza tornarse antropomórfica e devorar o homem - pois tanto o celeiro como o berracão estavam carcomidos, corroídos pela marisia ("were gray-bitten with sea salt") e o efeito sonoro con. sonantal de "beaten by the damp wind" aumenta e expande aincla mais esta conotação de violência física.

Aliás, esta última frase, com a força de seus verbos e a riqueza de seus efeitos sonoros (e por que razão um aluno de lingua não deveria percebè-los?) poderia até ser tran;formada numa frase poética:

The little shack
the rattling, rotting barn
were gray-bitten with sea salt,
beaten by the damp wind
until
they had taken on
the color of the granite hills.

A frase seguinte traz um pouco de diversidade à atmosfera desolada e à falta de colorido da linha anterior. Se a pequena cabana e o celeiro apodrecido assumiram a cor cin. zenta das montanhas de granito - num esforço mimético de sobrevivência talvez, como costumam fazer os insetos, dentro cleste panorama estéril, agressivo e imenso - os animais da fazenda não parecem tāo propensos às forças destrutivas do vento do mar (como sugerem "salty" $e$ "damp" na linha anterior). Sua descrição acrescenta um toque de cor a esta paisagem cinzenta: "two horses, a red cow and a red calf, half a dozen pigs and a flock of lean, multicolored chicken stocked the place". Mias até as galinhas são magras, sugerindo falta de alimento. Isto é novamente confirmado pela última frase deste trecho, pois "a little corn was raised on 
the sterile slope, and it grew short and thick under the wind, and all the cobs formed on the landward sides of the stalks". Os adjetivos "little, short, thick" em relação ao mliho, mais uma vez sugerem uma paisagem hostil, confirmada pela la. deira estéril ("sterile slope") e pelo fato de que o vento do mar era um empecilho para o crescimento das espigas nos talos que davam para o lado do mar.

Deste modo, fazendo o aluno ver as palavras impressas e depois visualizá-las, pode trazer resultados surpreendentes: ele irá perceber que, mesmo sem haver entrado en contato com a família Torres, já pode sentir a opressão de uma natureza antagônica, onipotente $e$ isoladora contra as tentativas fúteis das construções da fazenda de permanecer onde estāo, e dos animais e do milho em sobreviver na ladeira, através dos detalhes nítidos fornecidos pelos adjetivos e pelo efeito emocional dos verbos. Pois todos os adjetivos relacionados à fazenda transmitem a idéia de pequenez, decadência ou fragilidade, como já pudemos ver em "few acres, little shack, rattling, rotting barn, little corn, lean chicken, sterile slope" etc., enquanto os verbos acrescentam uma dimensão a mais de impotência e desamparo das construções da fazen. da - "gray bitten, beaten" - em relação à natureza.

Concentrando-nos mais uma vez em trechos expositivos, vamos examinar um outro parágrafo, para confirmar esta abordagem.

Quando Pepé deixa sua família e penetra na selva, a natureza, contrastando com a região em que ele mora, aparece como benevolente, maternal, fértil e pacifica, como que convidando o estranho a penetrar na floresta:

(...) It was a well-worn path, dark soft leaf-mold earth strewn with brcken pieces of sandstone. The trail rounded the shoulder of the canyon and dropped steeply into the bed of the stream. In the shallows the water ran smoothly, glinting in the first morning sun. Small round stones on the bottom were as brown as rust with sun moss. In the sand along the edges of the stream the tall, rich, wild mint grew, while in the water itself the cress, old and tough, had gone to heavy seed.

Como o aluno pode observar, este parágrafo aparentemente tão simples oculta mais uma vez uma riqueza de nuances que podem ser vistas mais claramente quando contrastadas com trechos posteriores. A trilha está bem usada ("well worn") sugerindo não oferecer dificuldade ao cavaleiro, pois ela também é trilhada por outros viajantes. Esta acessibili- 
dade é ainda intensificada pela fertilidade do solo, com sua terra escura, macia e vegetal ("dark soft leaf-mold earth") e do rio, no qual a água corria mansamente, brilhando nos primeiros raios do sol ("the water ran smoothly, glinting in the first morning sun"). Não há uma palavra áspera para anunviar este início esperançoso de uma nova etapa da vida do herói, tão bem metaforizada na suavidade do curso d'água e no amanhecer de um novo dia, a não ser que nos concen. tremos no detalhe de "broken pieces of sandstone", que poderia ser interpretado como uma espécie de premoniçāo da regiāo árida que Pepé encontrará mais tarcle. Mesmo assim, a impressão total é de paz, luz e abundância, pois "along the edges of the stream the tall, rich, wild mint grew, while in the water itself the cress, old and tough, had gone to heavy seed". Esta exuberância na natureza é novamente transmitida pelos adjetivos ligados aos substantivos "path, earth, mint" como também através do advérbio "smoothly".

Mesmo assim, é um caminho difícil e perigoso, pois "the trail rounded the shoulder of the canyon and dropped steeply into the bed of the stream". Podemos também visualisar a cena colorida proporcionada por este quadro, no qual as cores naturais da paisagem são realçadas, intensificadas pelo sol da manhā. E - falando agora especificamente a estudan. tes de literatura - a assim chamada "metáfora morta" na expressão "the shoulder of the canyon" parece adquirir nova vida, se a relacionarmos com a antropomorfização da natureza que logo será iniciada, e da qual já tivemos um indício prematuro em "bitten, beaten" no primeiro parágrafo.

Este quadro de uma atmosfera aprazivel nas primeiras fases da fuga de Pepé é gradualmente substituido por umas pinceladas que aos poucos se tornam mais e mais agourentas e adversas com o passar das horas e dos dias (magnificamente sugeridos pelo nascer e pôr do sol e da lua). Necessitamos apenas examinar mais alguns trechos descritivos para receber uma impressão da configuração total que se torna explícita através da magistral manipulação de palavras do autor:

\section{Primeiro dia:}

The trail grew very steep. Now the redwood trees were smaller and their tops were dead, bitten dead, where the wind reached them. The horse plodded on; the sun went slowly overhead and started down toward the afternoon. (...) Pepé turned in his saddle and looked back. He was in the open now: he could be seen from a distance. As he ascended the trail the country grew more rough and terrible 
and dry. The way wound about the bases of great square rocks. (...) The high mountain wind coasted sighing through the pass and whistled on the edges of the big blocks of broken granite. (...) The trail dropped quickly, staggering among broken rock. (...) A scar of green grass cut accross the flat. And behind the flat another mountain rose, desolate with dead rocks and starving little black bushes. (...) He held up his rifle on one side and his arm on the other to shield his face from the sharp brittle fingers of the brush. (...)

\section{Segundo dia:}

Gradually the sharp snaggled edge of the ridge stood out above them, rotten granite tortured and eaten by the winds of time. Pepe had dropped his reins on the horn, leaving direction to the horse. The brush grabged at his legs in the dark until one knee of his jeans was ripped. (...) The starved brush and rocks stood out in the halflight, strange and lonely in high perspective. (...) In the waste of the mountainside, the poor dry brush grew three feet high. Here and there, big outcroppings of unrotted granite stood up like moldering houses. Pepé relaxed a little. (...) Little dry avalanches of gravel and shattered stones went whispering down the hill behind him. (...) On the other side the hill rose up sharply and at the top the jagged rotten teeth of the mountain showed against the sky.

\section{Terceiro dia:}

(...) At last he was nearing the top. The moon showed the uneven sharp back of it against the sky. (...)

\section{Quarto dia:}

(...) Below him lay a deep canyon exactly like the last, waterless and desolate. There was no flat, no oak trees, no even heavy brush in the bottom of it. And on the other side a sharp ridge stood up, thinly brushed with starving sage, littered with broken granite. Strewn over the hill there were giant outcroppings, and on the top the granite 
teeth stood out against the sky. (...) His body struck and rolled over and over, starting a little avalanche. And when at last he stopped against a bush, the avalanche slid slowly down and covered up his head.

O aluno, ao se familiarizar mais e mais com o texto, será capaz de detectar relaçōes, paralelismos e contrastes entre estes diferentes trechos, que projetam a mudança que ocorre na natureza, preparando-nos para o desfecho da estória. Como se vê, não foi feito praticamente nenhuma referência às açōes de Pepé, pois nossa intenção aqui é despertar a sensibilidade do aluno ao ler trechos descritivos, que mais tarde ele poderá naturalmente ampliar para outros modos narrativos.

Mencionando apenas algumas destas relações, podemos delinear a mudança que ocorre na natureza simplesmente através dos adjetivos que acompanham os substantivos: a trilha se torna muito ingreme ("very steep"), as sequóias ficam menores e seus cumes estão mortos, carcomidos "smaller", "dead", "biten dead"). o que nos remete aos trechos jä analisados. A regiāo torna-se cada vez mais acidentada, terrivel e árida ("more rough and terrible and dry"), juntamente com o aumento do número de grandes rochedos quadrados ("great square rocks") sugerindo não apenas esterilidade mas também inacessibilidade e levando posteriormente ao antropofagismo, através do definhar, da inanição. Os adjetivos "dead", "desolate" e "starving" se repetem em intervalos cada vez menores e a vegetação está reduzida a uma cicatriz de grama verde ("a scar of green grass") novamente com implicações futuras na palavra "scar", que dá um toque agourento. E a natureza se torna enfim explicitamente antropomórfica, começando com "starving little black bushes", através de "the sharp little fingers of the brush" $e$ "the brush grabbed at his legs" para então tornar-se explicita e potencialmente antropofágica, com "the jagged rotten teeth of the mountain", depois repetidos em "the granite teeth stood out against the sky". Até que, como foi prognosticado em "little dry avalanches of gravel and shattered stone went whispering down (novamente personificação) the hill behind him" a natureza por fim o devora em sua inanição, após ele ter sido morto a tiros, pois a avalanche desliza lentamente ("slowly") cobrindo sua cabeça.

Esta mutação antropomórfico-antropofágica na natureza, que atinge seu climax no episódio em que a cabeça de Pepé é coberta pelo cascalho, é ainda mais intensificada e realçada por uma mutação zoomórfica em Pepé, mutação que funciona 
como contraponto, novamente através de uma série de palavras-chave que, tanto isoladamente como em grupo, sempre numa gr̊dação ascendente, projetam a onipotência da natureza sobre o homem e aumentam a eficácia do conto.

Se uma mudança da adolescência para a maturidade já ocorreu no inicio da estória, após Pepé ter morto um homem irrefletidamente - pois do rapazinho alto e sensivel de dezenove anos, tranquiilo e carinhoso, mas muito preguiçoso ("the tall, sensitive son of nineteen, a gentle, affectionate boy, but very lazy"), Pepe tornou-se um homem, como ele mesmo diz antes de fugir para a selva: "I am a man now, Mama. The man said names to me I could not allow." - é realmente quando cle penetra nesta selva que a mudança de homem para animal ocorre gradativamente, cotejando a fuga da civilização para a natureza. E esta metamorfose se inicia com a perd" gradual de suas vestes civilizadas e termina com sua identificação a um animal ferido ("a hurt beast") que, mesmo assim, ainda é capaz de morrer como um homem.

Pepé deixa o lar equipado com um cavalo, água e co mida, além da espingarda, do paletó preto e do chapéu que pertenceram a seu pai - e que tornam simbólica sua ligacão a seu defunto pai. Ao iniciar a viagem, ainda cercado por uma natureza benévola, rodeado pelas sequóias, Pepé se comporta de acordo com nosso código civilizado: "he drank from the water bag, and he reached into the flour sack and brought out a black string of jerky". Mas mais tarde, no mesmo dia, quando a paisagem começa a ter um aspecto mais estéril, ele já bebia parcimoniosamente do cantil e o arrolhou firmemente ("he drank sparingly from his bag and corked it tightly") - a força dos advérbios já sugerindo escassez. Da mesma maneira, Pepé também olhava para trás com desconfiança, suspeitosamente, a cada minuto aproximadamente, e seus olhos procuravam os cumes das cordilheiras à sua frente ("Pepé looked suspiciously back every minute or so, and his eyes sought the tops of the ridges ahead") pois ele estava no campo aberto. Apesar de cansado, a expressão de seu rosto ainda era inflexível, inquieta e varonil, como se confirmasse sua decisão de fugir. Isto é novamente enfatizado quando Pepé percebe que perdeu sua faca: "his face was blank, but it was a man's face". O medo se alterna com a esperança, pois ele examina a trilha acima apreensivamente ("apprehensively") e mais tarde adormece murmurando suas preces. Logo depois, novamente na alerta por causa do som do tropel de cavalos, Pepé prossegue na fuga, apenas para perceber que seu chapéu - uma proteção contra a natureza, como também o havia sido a faca - tinha desaparecido: ele o deixara. sob o carvalho. 
Ao se iniciar o segundo dia, o cavalo de Pepé é repentinamente morto e Pepé, ouvindo o eco de um outro tiro subindo a montanha, aiira-se desvairadamente atrás de um arbusto ("Pepé flung himself frantically benind a bush"). $E$ aqui que Pepé, até agora sempre aludido em palavras sugerindo medo mas masculinidade, humanidade, é descrito pela primeira vez em termos de um animal:

He crawled up the hill on his knees and one hand. (...) He moved with the instinctive care of an animal. Rapidly he wormed his way toward one of the big outcroppings of granite on the hill above him. Where the brush was high he doubled up and ran but when the cover was slight he wriggled forward on his stomch, pushing the rifle ahead of him. In the last little distance there was no cover at all. Pepe poised and then he darted across the space and flashed around the corner of the rock.

Como um animal acossado, Pepé continua a subir e, percebendo que está sendo perseguido mais uma vez, ele atira para dentro do matagal no caminho lá abaixo, apenas para receber de volta um tiro na mão. Aqui ocorre uma variação no tema do zoomorfismo, pois Pepé, para evitar o sangramento, "gathered a handful of spider web, and pressed the mass into the cut, plastering the soft web into the blood. The flow stopped almost at once". Aqui temos não o homem comportando-se como um animal, mas fundindo-se com a natureza para sobreviver. Esta mesma ação também adquire uma conotação premonitória, pois quando Pepé morre, ele também se unirá com a natureza.

A ação aumenta de intensidade com a alternância entre Pepé agindo como um homem - quando ele coloca um novo cartucho na espingarda - e como um animal: o verbo rastejar ("crawl") é usado sete vezes em rápida sucessão, juntamente com diversos advérbios, sugerindo um esforço cada vez maior no final:

(...) he slid into the brush on his stomach. Far to the right he crawled, and then up the hill, moving slowly and carefully, crawling to cover and resting and then crawling again. (...) Pepé crawled in the general direction of the ridge peak zigzagging for cover. (...) He crawled close to a rattlesnake before he saw it (...) When the sun slid past noon he had not gone a mile. He crawled exhaustedly a last hundred yeards to a patch of 
high sharp manzanita, crawled desperately, and when the patch was reached he wriggled in among the tough gnarly trunks and dropped his head on his left arm.

Esta identificação com o movimento de animais selva. gens é intensificada com sua gradativa perda de forças e o aumento de dor em sua ferida. Pepé tem até de se desfazer do paletó de seu pai, pois fazia pressão sobre seu braço inchado.

A luta pela sobrevivência continua, com Pepé tentando esconder-se como um animal na mata espessa, rolando montanha abaixo, procurando água. Seu zoomorfismo tornou-se tão patente que até um leāo das montanhas, perto dele, não tomou conhecimento de Pepé, pois parece reconhecer nele uma criatura irmã. Cada vez mais incapaz de se defender, Pepé deslisa dentro do matagal quase tão silenciosamente quanto o leão ("almost as quietly as the lion had") e este frenético correr animalesco é novamente projetado de forma magnífica através de uma série de verbos sugerindo uma fuga desesperada:

(...) In the darkening evening he crouched up the hill toward the next ridge. Only when the dark came did he stand up. His energy was short. Once it was dark he fell over the rocks and slipped to his knees on the steep slope, but he moved on and on up the hill, climbing and scrambling over the broken hillside.

A identificação de Pepé com animais atinge seu climax ao ele perceber que esquecera a espingarda no matagal e também ao se tornar intolerável a dor em seu braço inchado:

With the effort of a hurt beast Pepé got up and moved again toward the top of the ridge. (...) Up the steep hill he dragged himself a few steps and a rest, and a few more steps. (...) Pepés brain spun in a big spiral up and away from him. He slumped to the ground and lay still (...).

Sua desproteção como ser humano é contraponteada pelos sons animalescos que ele emite quando tenta dizer suas preces: "his tongue tried to make words, but only a thick hissing came from between his lips". E, ao iniciar-se seu último dia, Pepé, ainda consegue limpar a ferida, mas a dor penetrante o faz ganir como um cachorro. Mas, ao se apro- 
ximar sua hora final, Pepé parece reassumir sua virilidade, sua condição de ser humano, pois apesar de novamente emitir um sibilo indistinto dos lábios, ele consegue fazer um trêmulo sinal da cruz sobre o peito com a mão esquerda ("a shaky cross on his breast with his left hand").

O lado animalesco e o humano de sua natureza novamente se interpenetram em seus derradeiros momentos de vida, pois

(...) he crawled slowly and mechanically to the top of a big rock on the ridge peak. Once there, he arose slowly, swaying to his feet, and stood erect. (...) He braced his feet and stood there, black against the morning sky.

como se estivesse à espera de imolação pelos seus perseguidores misteriosos. Mas é aqui que o lado humano é valorizado, pois os animais agem apenas em funcāo das necessidades imediatas e seguem pelos instintos, enquanto o ser humano é capaz de antecipar os resultados de suas ações e de escolher os caminhos que vai seguir para alcançar seus objetivos. E Pepé, apesar de comportar-se como um animal ao rastejar até o alto, morre como um homem bravo, antecipando com sua açāo de erguer-se, sua imolação: pondo-se em pé novamente após o primeiro tiro, ele tenta pela última vez fazer o sinal da cruz, mas sua mäo esquerda tremulava in. defesa contra seu peito ("his left hand fluttered helplessly toward his breast") e, ao ser atingido pela segunda ba!a, ele oscilou para frente e caiu do rochedo ("Pepé swung forward and toppled from the rock") e seu corpo é então coberto vagarosamente por uma avalanche ("His body struck and rolled over and over, starting a little avalanche. And when at last he stopped against a bush, the avalanche slid slowly down and covered up his head").

Desta maneira, Steinbeck inverte a expectativa criada pelo uso do zoomorfismo, pois é exatamente pelo fato de Pepé ser gradativamente reduzido ao estado de um animal selvagem que projeta sua humanidade. Sua morte demonstra que o homem, mes: no completamente perdido na selva, ainda é mais do que um mero ser irracional, pois apesar de Pepé ter-se integrado com a natureza, como as premonições sugeriam, ele conseguiu superar seu ambiente natural e até seu zoomorfismo através de sua morte sacrificial, serena e heróica.

Concluindo, podemos perceber que, com este tipo de abordagem linguística, tanto examinando um parágrafo isolado ou estabelecendo relações através dos parágrafos em dife- 
rentes pontos da narrativa, podemos ajudar tanto os alunos nos estágios mais avançados de lingua quanto aqueles iniciando o estudo de textos literários, a desenvolver uma maior sensibilidade em relação à língua. Isto não pode ser adquirido apenas através de regras gramaticais ou através do uso de uma terminologia técnica de termos literários sofisticados, se os alunos nāo são capazes de ler, visualizar e pensar acerca das palavras impressas na página. E se eles estiverem apenas interessados em descobrir do que trata a estória, irão falhar novamente, pois nestes trechos descritivos não há nada à primeira vista que desperte o interesse em continuar lendo, se os seus olhos não forem abertos para a riqueza sugestiva da linguagem, que impregna quase todas as palavras no conto. Os alunos também deveriam ser conscientizados de que esta abordagem é apenas uma das múltiplas maneiras de se lidar com um texto, se bem que uma maneira básica. Estilo, personagem, enredo, tema, todos podem ser abordados através de uma leitura de texto, como o fizemos em relação ao espaço e à personagem principal, enfatizando a transformação antropomórfica e zoomórfica que neles ocorre. Se quisermos ir além, poderemos ainda examinar o contexto sociológico do conto, entre outras alternativas.

Desta maneira espero que os alunos continuem por conta própria a ler com sensibilidade, a ler cuidadosa e criticamente através dos outros trechos do conto "Flight" e que, quando chegarem ao fim, percebam que literatura é língua, afinal de contas.

\section{SUMMARY}

This article intends to show how literary texts can be clealt with much more easily through a close reading, which allows students to perceive how language is structured into literature. Descriptive passages from Steinbeck's short-story "Flight" were chosen for this purpose, which show on the one hand, how nature becomes anthropomorphic and, on the other hand, how the hero, Pepé, gradually suffers zoomorphic changes, thus intensifying the relationships between setting and character.

\section{BIBLIOGRAPHICAL REFERENCES}

STEINBECK, John. Flight. In: The Long Valley. New York „Bantam Books, 1970. p. 26-46. 